The Brock Review Volume 12 No. 2 (2012)

(C) Brock University

\title{
Why Canadians Can't Write Musicals
}

Jim Betts

\begin{abstract}
The Canadian Musical Theatre community may include talented writers, directors and producers, but it does not exist in a properly functioning professional environment. In some respects, the Canadian Musical Theatre is closer to an "oral tradition" than a 21st Century art form. The community lacks leadership, focus, and resources. There is a significant need for effective training programs and realistic, well-supported development opportunities. The history of the Canadian Musical Theatre has some similarities to the history of the American Musical Theatre, but its development may lag about 50 years behind.
\end{abstract}

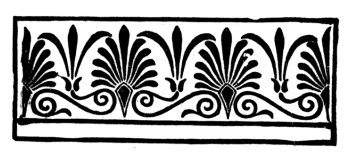

Why can't Canadians write musicals?

This may seem like an odd time for such a question, especially given the recent enormous success of The Drowsy Chaperone. And given too that there do seem to be a lot of Canadian Musicals being written and produced at the moment, many of which were showcased at the recent Lyric Canada conference, is there any justification at all in even asking such a question?

The Drowsy Chaperone aside, what about Anne of Green Gables? What about Billy Bishop Goes to War? What about The House of Martin Guerre? Evil Dead - The Musical? My Mother's Lesbian Jewish Wiccan Wedding? What about...? Everyone will have other names to add to that list, so it may in fact be clear that Canadians can, and do, write plenty of musicals.

Perhaps, then, the more important question is: are they "good" musicals? Do they deserve to be considered with the best musicals from around the world? An even larger question is, even if a good Canadian musical script and score should happen to be written, are there Canadians with the skill and experience to successfully direct, choreograph or produce it. 
The short answer? No.

In fact, there is an argument to be made that it's no wonder we can't write musicals, when essentially no one really takes musicals seriously in this country - not the writers, the producers, or even the audiences. The truth is that, on the whole, the Canadian Musical Theatre is unprofessional its writers, its directors and its producers. If a professional is someone who has committed to a particular life's work, who has studied the craft and the history of their profession, who has attempted to learn from the people who have been there before, and to keep in touch with what is being created by their contemporaries, who in the Canadian Musical Theatre qualifies? If a professional is someone who does not accept "good enough" as good enough, who in the Canadian Musical Theatre is prepared to work that hard?

Those of us who write, direct and produce musicals in this country have no real idea what we're doing. It is not necessarily that we don't want to be professional, or that we don't have the talent to be, but that the culture of new musical theatre in Canada hasn't matured enough yet to encourage or support the development of genuine musical theatre professionals.

Anyone who has ever been in a lyric-writing class, or has sat in on a dramaturgy session with an inexperienced lyricist, has heard some variation of: 'Yes, I know that line doesn't scan very well, and yes, that is an imperfect rhyme--but I've worked on it and I don't think there's any other way to say what I want to say. I'd rather be true to the idea, the meaning of the line, rather than be a slave to the craft." There's an anecdote about Oscar Wilde being quoted as saying, "I have spent most of the day putting in a comma and the rest of the day taking it out." There's a story that Oscar Hammerstein spent a week deciding whether his lyric should be "What a beautiful morning" or "Oh, what a beautiful morning." A Stephen Sondheim lyric, or a Leslie Arden lyric, doesn't rhyme and scan by accident. Stephen Sondheim and Leslie Arden work at it. Commit to it. They understand their craft. They're professionals.

I accept that I have just contradicted myself. In one breath I say that Canadian Musical Theatre writers are unprofessional, and in the next I identify Leslie Arden as a professional. In fact I believe that she is not the only professional musical theatre writer in this country, but I would challenge you to name too many more: writers who live and work in Canada, who work virtually exclusively writing musical theatre, and who make their living doing it. That may be too narrow a 
definition, but it's sobering to think of it that way. If one adds to that list writers who may write a show or two a year, or a show or two every ten years, suddenly maybe one has to use up to two hands to count them. But even when they write a show, how much time do they actually spend writing it, or more importantly, re-writing it - how much craftsmanship and professionalism go into it? We will leave David Warrack out of this equation because he can write a new show in the morning, finish the orchestrations in the afternoon, and still have time to coach his son's hockey team that night.

So, yes, there are exceptions, but the truth is that far too many members of the Canadian Musical Theatre community are content to accept "good enough" as good enough. Many believe that basic musical theatre craftsmanship is old-fashioned. But is craftsmanship not essential to any successful work of art? Is there any art without craft? Would it not be foolhardy to ride in a boat, or stand on a balcony, built by someone who doesn't think craftsmanship is all that important? The current situation is discouraging. But, frankly, how could anyone expect it to be anything else? Where does an aspiring young Canadian Musical Theatre writer go to learn the craft?

There is nowhere in Canada to go. The sad truth is that there is currently no effective culture of professional musical theatre creation in Canada. This wasn't always true--there used to be a few theatre companies in Canada that worked hard to produce new and exciting original Canadian Musical Theatre. But those companies are now either no longer in business, or at least, in one particular case, apparently no longer in the business of new Canadian Musical Theatre.

I'm really not sure why this is. Audiences like musicals. Audiences even like bad productions of musicals. Musical theatre is among the most popular and lucrative theatrical traditions in the world. Regional theatres, and world-famous classical theatre companies, program musicals to generate enough revenue to produce the shows they really want to produce. It would only make sense that we try to exploit this resource, that we become more entrepreneurial in our approach to creating lucrative new musical theatre. And wouldn't it make sense to start by trying to nurture "professional" new musical theatre creators.

But if being a professional involves some sort of understanding of the history of one's art and craft, maybe one of the most significant issues with Canadian Musical Theatre is that in many ways we actually have no history. Or at least no access to, or appreciation of what history there is. 
Here we are in the 21st Century, in the most advanced technological era in the history of mankind, and to a large extent the musical theatre in Canada is still an "oral tradition."

Look at one of the most successful, influential and revered shows in Canadian Musical Theatre history--The House Of Martin Guerre. It's not an exaggeration to say that this show is a bit of a legend in Canada - legend being a particularly appropriate word, I think, because it literally doesn't exist anywhere but in our memories. We hear about this show, we talk to people who actually saw this show, but anyone who wasn't in one of the theatres in which it played has no real idea what it looked or sounded like. You can't purchase a script, there is no Original Cast Recording, there is no PBS Masterwork video. I could let you listen to my pirated recording, but I would be breaking the law. The one published song from the show isn't even the same version as was sung in the production.

Canadian Musical Theatre history is best taught late at night, around a campfire, when the old storytellers and musical theatre elders tell tall tales of Spring Thaw, Rockabye Hamlet and The House Of Martin Guerre.

I suggested earlier that I don't think we take musicals seriously in this country. I will go even further and suggest that in fact our broader theatre community doesn't really like musicals very much. Musicals aren't respected in Canada as a legitimate "art form." I don't know how many times I've heard someone from "the serious theatre" tell me that they don't like musicals. Until the day they actually see a good one.

As a young man, I had occasion to visit a friend who was living for a time in Jamaica. He was off at work one day and I was poking around the kitchen preparing to make myself some lunch. I opened the refrigerator and saw a bowl of something I didn't quite recognize, took out the bowl and had a taste of what was in it. I couldn't believe what happened next--my taste buds started dancing-singing and dancing, and then suddenly they were being accompanied by a 60-piece orchestra. Never in my life had I tasted whatever this miraculous thing was! Except I had. It turned out it was pineapple. But it was real pineapple, fresh off the tree, and totally unlike any pineapple I had ever eaten, banished as I had apparently been all my life to the tropical fruit wasteland of the Canadian tundra.

Most of us don't really see many well-written, well-produced musicals. My experience is 
largely in Canada, but I'm willing to wager that this is also the case south of the border. Successfully writing and producing musicals is an extremely complicated process. The ones that turn out well are usually the result of some sort of alchemical combination of professionalism and magic. Unfortunately, our audiences are too used to seeing relatively mediocre musicals. This may well be the case in other theatrical genres as well - perhaps the same could be said of the serious theatre, opera and dance. I can only say that my observations are based primarily on my experience with seeing musicals--new and classic.

It is relatively easy therefore to dismiss musicals as silly or unimaginative or amateurish if one is used to seeing primarily silly and amateurish productions. I believe that a large part of our musical theatre audience has been conditioned to mediocrity. Large-scale musicals--Guys And Dolls, Les Miserables--rehearsed in as little as 10 days and then offered to paying, if unwary audiences. Some theatres offer their audiences one musical a year largely because musicals tend to sell better than "serious theatre." This isn't a slight against "serious theatre," it's simply a statement of theatrical fact. But this can make people in the "serious theatre" a bit cynical, and some theatres don't feel they really need to put as much effort into producing a musical because audiences are going to accept it regardless of how effective the production really is. Like it or not, the reality is that an uninspired production of Annie will still likely outsell a well-considered production of an Ionesco play, or of a new work by an exciting but as yet unknown new Canadian playwright. Musicals are often scheduled into a season as revenue generators to help support the more serious aspects of a theatre's mandate a situation that again can lead to cynicism and resentment.

It is often a revelation then, when someone who has always "hated" musicals suddenly finds him or herself watching one that actually works as it was designed to work. How many of us, even those of us who appreciate and love musicals, have grown to dismiss a show like Oklahoma as quaint, or dull, or old-fashioned until suddenly we see a well- rehearsed, well-considered, well-cast production of the show?

I was cursed at birth. On the night I was born, South Pacific opened on Broadway, and in retrospect it was a bit like I was cosmically and metaphorically bitten on the neck by the vampire of musical theatre. I loved listening to the South Pacific cast recording as I grew up--my parents actually used to have it in their music rotation, and would play it on their record player in the evening after I had gone to bed. But I was always a bit disappointed whenever I saw a production of it--dinner 
theatre seems not perhaps to be the optimum venue for a South Pacific production--but I did see one in such a place while eating my roast beef and cheesecake, with umbrellas floating in my drink. And then I saw the recent Lincoln Centre production, and suddenly it was like discovering what pineapple really tastes like. The hair stood up on my arms. I realized at one point that I wasn't just watching a museum piece, I was watching a drama about racism, and intolerance--a drama that one suddenly remembers actually won a Pulitzer Prize--but a drama in which every five minutes or so someone would sing an incredible song, and the hair on my arms would stand up again. My guess is that they rehearsed that production for longer than 10 days.

An understanding of history is an essential element in creating a more effective present and future. So, too, our understanding of the current state of Canadian Musical Theatre demands some understanding of how we got to where we are (or, I suppose, where we aren't).

There can be no doubt that the Musical Theatre is an American Art Form. Invented by Americans, perfected by Americans, and perhaps most important of all - respected and loved by Americans. The odd British Lord has managed to have some success in the musical theatre, of course, as well as a couple of French writers, and a Swedish pop group, but by and large the history and creative growth of the musical theatre has been driven by the passion and creativity of American writers and composers.

Most Musical Theatre History 101 courses will identify a number of significant milestones in the development of the art form. The Princess Musicals, circa 1910-1920, are often considered to be the first turning point--where shows changed from being imitations of European Operettas to becoming more American--telling American stories with an American sensibility. Jerome Kern was at the heart of this change, and 1915 is often identified as the year he wrote his first real American Princess Musical. 1915--remember that date. The next significant milestone is often considered to be Showboat in 1927/28, a major attempt to tell a serious American story in words and music. The beginning of the Golden Age of The American Musical Theatre arrived in 1943 with the opening of Oklahoma-famously dismissed ahead of its opening as having "No girls, no gags, no chance," and managing instead to change the musical theatre forever.

My personal favourite American Musical Theatre year is 1957--marking the transition from the first Golden Age to the second. Musical Theatre geeks will know that the Tony Award winner in 
1957 was The Music Man, as wonderful and joyful an example of the well-made musical as any ever produced. But 1957 was also the year that featured the opening of arguably the best American Musical ever written--a show that didn't win the Tony, but went on to become a legend. I'm referring, of course, to West Side Story, not coincidentally also the show that introduced Stephen Sondheim to Broadway.

I mention these dates because I have an odd little theory of how the history of the Canadian Musical Theatre lags almost exactly 50 years behind that of our American neighbours. Too close an analysis of this theory will cause it to fall apart in all sorts of ways, but it gives me hope that we still have the potential for our own glorious musical theatre future.

I have taught a course in the History Of The Canadian Musical Theatre the past few years, and I built that course around a few milestones that I think mark our own musical theatre development. Apropos of nothing, I chose to accept the suggestion that the first Canadian musical was written in 1606, when Samuel de Champlain's famous Order Of Good Cheer produced Theatre de Neptune, the show after which the Neptune Theatre was named. 1606--that date will be on the test. But I digress, as that has nothing to do with my thesis. In putting together my course, I identified 3 significant eras: the Mavor Moore era, the John Gray era, and the Leslie Arden era. I have a certain hero worship for all three of these artists.

I don't think it's any real exaggeration to consider Mavor Moore to be the Father of Canadian Musical Theatre. He was a remarkable man, and one of the most important figures in the history of Canadian culture. A writer, composer, actor, director, producer, administrator, and mentor, he played a significant role in the founding of CBC Television, the Neptune Theatre, the St Lawrence Centre and, most significant to this discussion, The Charlottetown Festival. He was the first artist to head the Canada Council. He wrote stage plays, radio plays, musicals and opera libretti. He was a Canadian cultural Renaissance man, and he was at the vanguard of the Canadian cultural nationalism that exploded in the 1960s and 1970s. He co-wrote and directed Spring Thaw, the Canadian musical revue and cultural institution that ran every year from 1948 to 1965. He was committed to writing and producing shows based on Canadian stories--his own subject matter included adaptations of Stephen Leacock, the musical Johnny Belinda, and the opera Louis Riel. While at the CBC he commissioned the original television version of Anne Of Green Gables, then commissioned the stage adaptation that opened the Charlottetown Festival in 1965 and has been running there every year since. 
Moore was vocal about wanting Canadians to see their own stories written by, produced by and starring Canadians. The Charlottetown Festival was established in 1965 as a Festival of Music and Laughter, to tell Canadian stories to Canadian audiences. He soon refocused it as the home of new Canadian Musical Theatre. Canadian musicals by Canadian writers for Canadian audiences. 1965. 50 years exactly after the Princess musicals in New York City did the same thing for American musicals.

Mavor Moore came from the era of the "well-made musical." His musicals were clearly influenced by Rodgers and Hammerstein, and Lerner and Loewe, and the first Golden Era of American musicals. One of the great teachers of how to write the "well-made musical" was Lehman Engel--a Broadway conductor and composer who started teaching the craft of writing for the musical theatre in 1961. Although he died in 1982, BMI in New York still sponsors the Lehman Engel Musical Theatre Workshop in his memory, and many of Broadway's most successful writers and composers have come through that program. Those of us in Canada in the 1970s were extremely fortunate that Lehman Engel actually taught in Toronto for many years. The 1970s were a great time to be a musical theatre writer in Canada, and particularly in Toronto--sometimes there were even 3 or 4 or 5 original Canadian musicals all playing in Toronto at the same time, many of which were written by students in Lehman Engel 's Toronto workshops: David Warrack, James Saar, Joey Miller, Leslie Arden - and yes, I was there, too.

I mention Lehman Engel in reference to the well-made musical because John Gray - after whom I named my second significant era - was once quoted as saying that he "wouldn't take a Lehman Engel class to save (his) life!”

John Gray was born in Ottawa, brought up in the Maritimes, studied at UBC, and then settled in Vancouver. He started his own theatre company in BC in 1972, then worked with Theatre Passe Muraille in Toronto starting in 1975 where he began composing for the stage. His first musical was $18 \mathrm{Wheels,} \mathrm{a} \mathrm{musical} \mathrm{about} \mathrm{truckers.} \mathrm{Of} 18 \mathrm{Wheels}$ he says: "The musical is still performed, I think because it appeals to people who find plays embarrassingly voyeuristic. Outside the major centers, people are more comfortable with the oral tradition of the storyteller."

There does seem to be an "oral tradition" element to many of John's musicals, an elimination of the theatrical "fourth wall," that lets characters speak directly to the audience. In 1978, his most 
successful musical was produced, Billy Bishop Goes To War, co- written with actor Eric Peterson. It was a show for 1 actor and 1 piano player--essentially a monologue addressed to the audience--and in many ways it changed the face of the Canadian Musical Theatre, an ironic twist because I don't imagine that John and Eric ever really considered that they were even writing a musical. They were telling a Canadian story, and using monologue, theatricality and song to tell it. Those of us in the Canadian Musical Theatre appropriated it as a Canadian Musical. Thanks to American film icon Mike Nichols, the show played on Broadway, and at one point in the 1980s it was the most produced show in North America.

Mavor Moore and John Gray may not have agreed on the importance of writing in the style of the "well-made musical," but they still had a lot in common. They were both interested in telling Canadian stories from a Canadian point of view. Billy Bishop Goes to War, 1978--50 years after Show Boat first played on Broadway.

Leslie Arden on the other hand, is not particularly interested in telling Canadian stories at all, simply in telling good stories well. Her writing style is far closer to the "well-made musical" of Mavor Moore than to the oral tradition of John Gray, but Mavor Moore was influenced by the First Golden Age of the American Musical, whereas Leslie Arden is far more a part of the Second Golden Age, far closer to Stephen Sondheim than to Rodgers and Hammerstein. In fact, Leslie studied with Sondheim, and her sophisticated writing style, and her complicated and deep approach to character, puts her in the same league as many of the best musical theatre writers writing anywhere in the world at the moment. Leslie's most significant show to date has probably been The House Of Martin Guerre. Her show with Norm Foster, The Last Resort, has had far more productions and I expect made her far more money, but it is The House Of Martin Guerre that marked Leslie's transition into one of Canada's most respected and important musical theatre writers.

The history of Martin Guerre is an interesting study in itself. It made its debut in Toronto in 1993 in a production by Theatre Plus, a production which in retrospect Leslie considers to have been a great professional workshop for the version of the show yet to come. It was produced again, in a new production, by The Goodman Theatre in Chicago in 1996, this time with a new book collaborator, an American creative team, and a full orchestra. That production was essentially remounted the next year at CanStage back in Toronto, and was a tremendous success. It was perhaps the most significant single advance of Canadian Musical Theatre onto the international scene. Yes, 
the American production was in Chicago and not on Broadway--partly as a result of there being another Martin Guerre musical, the Schönberg/Boublil version, in development around the same time --but it made its mark. It was a major step forward in the evolution of the Canadian Musical Theatre. First produced in Toronto in 1993, 50 years after Oklahoma revolutionized the American Musical Theatre.

My last entry in this fun-with-numbers game is The Drowsy Chaperone, without a doubt the most successful fully-Canadian-written musical ever to play on Broadway. (I'm not counting the shows that Galt MacDermott co-wrote with American collaborators, Hair and Two Gentlemen of Verona, for example). Most of us know at least a little about the history of The Drowsy Chaperone--how it started as a stag party presentation in 1997, became a Toronto Fringe Festival hit, played a small commercial production at Theatre Passe Muraille (first Toronto home to Billy Bishop), became a major Mirvish commercial production at the Winter Garden theatre, then went on a redevelopment journey through a variety of American Musical Theatre Festivals and productions, then arrived on Broadway in 2006, winning Tony Awards for all four of its Canadian writers.

2006--50 years (minus 1) after my favourite Musical Theatre Year, 1957. 49 years after The Music Man, West Side Story and My Fur Lady. (No, not My Fair Lady--that opened on Broadway in 1956.) My Fur Lady was a Canadian musical that was written and produced in 1957. It was a satiric reworking of the themes in My Fair Lady, and its initial run was so successful that it ended up doing two tours of Canada, played the Avon Theatre in Stratford and the Royal Alex in Toronto, and generated its own Original Cast Recording. Who produced it? A group of college students from McGill University--a group that happened to include soon-to-be-famous director/choreographer BrianMacDonald and a young Montreal composer named Galt MacDermott. Small musical with modest ambitions, captures public fancy, garners national recognition, gets recorded on vinyl LP-sound familiar?

Three more observations on The Drowsy Chaperone:

Comedy is a well-recognized Canadian export. American film and television projects are littered with Canadian actors and writers. SCTV and Saturday Night Live are two of the most celebrated examples. It shouldn't come as a great surprise then that The Drowsy Chaperone came less from the world of Canadian Musical Theatre and more from the world of Canadian comedy. Bob 
Martin started in that world, and Lisa Lambert was better known for her satiric and comic songs than for being part of the Canadian Musical Theatre establishment - if there even is such a thing. Thinking back, perhaps the first Canadian Musical ever to play on Broadway, way back in 1921, was the unforgettable Biff, Bang, Bing, written and performed by The Dumbells, the SCTV of its day. More recently, Evil Dead - the Musical again came more from a comedy tradition than a traditional musical theatre one. Even Anne Of Green Gables had its book written by none other than that Canadian comedy icon, Charlie Farquharson (a.k.a. Don Harron). The Spring Thaw satirical revues ran every year for almost 20 years, My Fur Lady was a satiric take on the Broadway hit of the year before, and Wayne and Shuster were a part of the Charlottetown Festival's first season.

Observation number two, and this relates back to the earlier comment that maybe we can write musicals, and that maybe the real issue is that we can't direct or produce them. As much national pride as we take in the success of The Drowsy Chaperone, and The House Of Martin Guerre, we do need to acknowledge the role that American Musical Theatre expertise played in both shows' ultimate success. Both of these shows had significant large-scale productions in Toronto--Martin Guerre at The Premiere Dance Theatre produced by Theatre Plus, and The Drowsy Chaperone at The Winter Garden produced by Mirvish Productions. But it was neither of these productions that eventually established the international reputations of the shows. Both shows ended up being reworked in American theatres, with American directors and choreographers, before returning to Toronto again with the reputations they now enjoy.

So how do we get to the point where we can earn this level of success on our own?

And this brings me to my final observation about The Drowsy Chaperone. I don't know about you, but if I had been asked 10 years ago what Canadian would end up winning a Tony for writing a Broadway Musical, the top name on my list would not have been Don McKellar. Independent film, sure; cutting-edge theatre, of course; but musical comedy? In fact, as a young man, McKellar freely admits that he was one of those artists I mentioned earlier--a serious-minded theatre student who dismissed musicals as silly and irrelevant. Until he was cast in a musical (ate his pineapple) and had his life changed. More to the point, he developed a relationship with a woman who was the MD on that musical, and who just happened to be a Broadway composer and lyricist. Marian Grudeff, a Canadian musician and writer, had been involved in many Spring Thaws, moved to New York in the early 1960s to seek her fortune, and ended up with a show on Broadway as one of the songwriters 
for Baker Street, a successful musical of the time based on the Sherlock Holmes' stories. McKellar credits Grudeff with having helped him, and Lisa Lambert, learn how to write musicals.

Is this, then, the basic issue? If it's true that we in the Canadian Musical Theatre don't really have any coherent idea how to write, direct or produce effective musical theatre on our own, how do we get to the point where we finally will know what we're doing? Stephen Sondheim probably didn't need much help in learning how to write musicals, but it can't have hurt that he did in fact have a teacher and mentor when he was a young man--no less a musical theatre icon than Oscar Hammerstein II himself. No one probably needed to help Leslie Arden very much either, but it can't have hurt that she got an opportunity to learn a little from Lehman Engel and then a lot more, in turn, from Stephen Sondheim. Don McKellar, it turns out, had Marian Grudeff. So where do the rest of us go to get that kind of help?

There is a culture of professional musical theatre training in the U.S.--including courses in Musical Theatre Writing, the grand-daddy of which is The Lehman Engel Musical Theatre Workshop in New York City. Some American universities actually have courses in writing for the musical theatre--some even offer advanced degrees in musical theatre writing. My head spins! In Canada, we have university and college courses in playwriting, and in classical composition, but none in the craft of writing or composing for the musical theatre. We have courses around Canada in training to perform in the musical theatre, but none in writing for the musical theatre. Where do aspiring musical theatre creators go in Canada? If in fact they choose to go anywhere at all. I still think there are a number of people writing musical theatre in Canada at the moment who have the attitude: we don't really care how it's supposed to be done, this is how we're going to do it. Which is of course their right. Just don't ask me to stand on the balcony they build. In fairness, of course, John Gray went his own way and that turned out pretty well. Sometimes talent is all you need. But for the rest of us, I wouldn't mind a little help.

And off and on through the years there has been a little help. Mavor Moore blessed us with The Charlottetown Festival in 1965, and under the inspired leadership of Allan Lund it was a pretty exciting place to be for everyone in the Canadian Musical Theatre for about 20 years. Regrettably, that isn't really the case at the moment, and in fact The Charlottetown Festival has not produced a new Canadian Book Musical on its main stage this century. Lehman Engel was an inspiration to many of us through the 1970 's, and I don't think that it's a coincidence that there may have been 
more successful Canadian Musicals written and produced in the 1970's and 1980's than perhaps any time before or since. After Lehman's death in 1982, we formed what we called The Guild Of Canadian Musical Theatre Writers to try and carry on the work that Lehman had been doing. It flourished for a few years then disappeared. A small theatre company called The Group Of Several started commissioning and producing original Canadian Musicals in the 80's, many of which went on to successful professional productions. It flourished for a few years then disappeared. The Muskoka Festival in Gravenhurst started concentrating on producing new Canadian Musicals, and even started its own Muskoka Festival Musical Theatre Colony. More shows came out of that, some of which are still being performed. It flourished for a few years then disappeared. The CBC used to produce original musicals on a regular basis--they don't anymore. In the 90's we had the ACLCL (The Association of Canadian Librettists Composers and Lyricists), and we had CAMTA (The Cabaret and Musical Theatre Alliance)--both of which flourished for a few years then disappeared. Recently we've had Musical Theatre Works in Vancouver, which is still active. And Script Lab in Toronto, which produced our first Canadian Musical Theatre Festival a few years back then almost passed out from exhaustion. Most of these organizations were run by volunteers--we meant well, we tried hard, we passed out from exhaustion.

Perhaps more than any other art form, Musical Theatre relies on inspired and professional collaboration. It may be one of the most difficult art forms in the world to get right. Therefore, the larger the creative team of collaborators, the harder it is to make sure that everyone knows what they're doing. Or to get everyone working on the "same" show. Like the proverbial group of blind scholars trying to describe what an elephant looks like. It starts with the writers, but it goes all the way up the food chain through the orchestrator, the director, and a dozen other levels to the executive producers at the top. That is a lot of people to train. If any single person on that chain is making it up as they go along, the whole project is in trouble.

So what do we do?

We could carry on as we are, essentially as amateurs. Some of us, perhaps many of us, are inspired amateurs to be sure. But the majority of us are whistling in the dark, content with what seems good enough. Writers who aren't quite sure what they're doing, collaborating with directors who aren't quite sure what they're doing. Every once in awhile something quite good may be created, but the sad irony will be that we won't be quite sure how or why it was good, and we won't be able 
to figure out how to do it a second time.

Any of us who are really serious about musical theatre will be tempted to give up and move to New York. Brian Hill and Neil Bartram made the choice to move there a few years ago, Neil joined the Lehman Engel workshop, and their small musical The Story Of My Life opened on Broadway in 2009. Jonathan Monro is in New York now. And unless things change here, more will follow.

The best solution might be for Wayne Strongman to abandon new opera and save the Canadian Musical Theatre for us. Of course, new opera would be unhappy with us, so better perhaps we identify our own Wayne Strongman and give that person the resources necessary to start building what we need here: a foundation upon which we can create a true professional musical theatre community--training, mentorship, development, and production. We have a number of exciting writers - including real professionals like Leslie Arden and Allen Cole - and the many writers with work showcased throughout the Lyric Canada conference. But their work needs informed professional support -dramaturgy, workshops, direction, production. All that takes training, development, money - but most of all professional, competent and committed leadership.

And if we do decide to make some changes, let's make one big change--let's stop being so damn nice to each other. We get so excited when someone, anyone, is brave enough to write a new musical, that we give them all the love and support we can muster. We give standing ovations to some of the worst musicals ever written, because we're just so happy and amazed that someone was actually willing and able to write one. Obviously, there is a big place in the musical theatre community for love and support--without it we might all have given up long before now. But we do need to be cautious. Yes, let's support the effort, and encourage the process, but let's not all start seeing the Emperor's New Clothes.

Let's start raising the bar. Let's start demanding more. A successful and vibrant Canadian Musical Theatre is in everyone's best interests--artistically and financially. There currently are a number of new initiatives, spear-headed by an impressive group of prominent Canadian theatre artists, focused on trying again to create an effective development process for the creation of new Canadian Musical Theatre projects. No doubt the entire community will cheer those artists on and wish them well. Let us all hope that they find the formulae, support and stamina, that earlier 
organizations failed to find. Until someone, or some organization, or some inspired group of likeminded artists, does manage to reinvigorate the community, the Canadian Musical Theatre seems destined to continue to struggle. Our writers, directors and producers need more effective tools-better training, smarter support, a more coherent infra-structure, and, most importantly, more rigorous self-assessment.

If Canadians wish to be taken more seriously in the larger Musical Theatre world, we need to take our own training and development more seriously. We need to recognize our real limitations and be more honest about our own willingness, or lack of it, to do what needs to be done. Talent isn't the issue - Canada is blessed with perhaps more than our share of talented artists. But talent on its own is not enough. Acceptance of "good enough" is never good enough.

We need to become professionals. 